\title{
PRAKTIK PEMERINTAHAN PADA KESULTANAN BUTON TAHUN 1540-1960 MASEHI
}

\author{
Muh. Ide Apurines \\ Mahasiswa Program Pascasarjana Studi Ilmu Pemerintahan FISIP \\ UNPAD \\ E-mail:muh16004@mail.unpad.ac.id \\ Muradi, Dede Sri Kartini \\ Dosen Program Pascasarjana FISIP UNPAD \\ E-mail: muradiclark@gmail.com; dedesrikartini@yahoo.com
}

\begin{abstract}
Abstrak
Penelitian ini berfokus pada praktik pemerintahan Kesultanan Buton Tahun 1540-1960 Masehi. Penelitian dilakukan di Pulau Buton Kota BauBau Sulawesi Tenggara dengan menggunakan jenis penelitian sejarah-kualitatif. Tujuan dari penelitian adalah mengetahui proses pemerintahan yang berjalan di Kesultanan Buton dari tahun 15401960 serta untuk mengetahui adanya praktik demokrasi yang terdapat di Kesultanan Buton. Teori yang digunakan dalam penelitian ini adalah teori demokrasi yang digagas oleh Robert A. Dahl. Teori tersebut menawarkan kriteria untuk mencapai pemerintahan demokratis untuk menilai sejauh mana demokrasi berjalan di Kesultanan Buton. Selain teori tersebut, peneliti juga menggunakan metode pengumpulan data heuristik yang terdiri dari studi pustaka dan dokumen serta wawancara. Hasil dari penelitian ini adalah: (1) Kesultanan Buton mempunyai bentuk pemerintahan yang berubahubah dikarenakan proses transisi kerajaan menuju kesultanan; (2) adanya praktik demokrasi dalam proses penyelenggaraan pemerintahan di Kesultanan Buton; (3) struktur pemerintahan yang berbeda dengan kerajaan/kesultanan pada umumnya, yang telah mempraktekkan struktur pemerintahan modern; (4) konstitusi tertulis Murtabat Tujuh menjadi dasar bernegara di Kesultanan Buton.
\end{abstract}

\section{Kata Kunci: Pemerintahan, Konstitusi Tertulis Murtabat Tujuh}


Muh Ide Apurines: PRAKTIK PEMERINTAHAN PADA....

\section{Pendahuluan}

Penelitian ini berfokus pada praktik pemerintahan yang terdapat pada Kesultanan Buton pada tahun 1540-1960, yang dilakukan pada bulan Juli tahun 2017, yang berlokasi di Provinsi Sulawesi Tenggara, Pulau ButonKota Baubau. Penelitian ini bertujuan untuk mengetahui bagaimana praktik pemerintahan yang di jalankan dalamKesultanan Buton di tahun 1540-1960. Dalam penelitian ini, peneliti memperoleh data melalui beberapa teknik pengumpulan data yaitu, dari data primer yang bersuber dari data heuristic (studi pustaka dan dokumentasi) serta data sekunder yang bersumber dari wawancara. Disamping itu, peneliti juga akan memaparkan bagaimana sistem pemerintahan berjalan di Kesultanan Buton dapat dilihat dari proses-proses pemerintahan sejak masa Sultan Buton pertama hingga Sultan Buton ke 37.

Kata "Buton", digunakan sebagai nama Kesultanan yang akan menjadi objek kajian penelitian ini, adalah nama sebuah pulau, yaitu pulau Buton. ${ }^{1}$ Dipulau inilah terletak pusat pemerintahan Kesultanan Buton. Nama ini berasal dari nama jenis pohon,yaitu pohon butun. ${ }^{2}$ Tidak diketahui, sejak kapan pulau itu bernama demikian. Yang pasti, sejak masa Gajah Mada menjadi patih Kerajaan Majapahit, Buton telah dikenal di Jawa. Hal ini dapat diketahui dari kakawin Nagartagama Karangan Mpu Prapanca. Prapanca dalam kitabnya menyebut sumpah Gajah Mada yang dikenal dengan "Sumpah Palapa".

Dalam kitab tersebut telah di temukan nama Butun sebagai bagian dari Kerajaan Majapahit pada masa kekuasaan

\footnotetext{
1Orang-orang dulu di negeri ini menyebutnya "Buton". Bukan "Butun". Orang bugis-makassar juga menggunakan sebutan pertama. Sebutan pertama sangat dikenal di kota Makassar dikarenakan di kota Makassar terdapat suatu tempat yang bernama kampong butun, pasar butun dan jalan butun. Lihat ligtvoet, beschrijing en Geschiedenis van Buton, BKI, Vol. 26, 1878, hlm 1.

${ }^{2}$ J.C. Anceaux, Wolio dictionary. 1987. Hlm 25. Orang Buton menyebut Pohon ini dengan "butu". Dalam dunia ilmiah pertumbuhan ini dikenal dengan Barringionia asiatica. Lihat Poerwadarminta. Kamus umum bahasa Indonesia, 1978, hlm 25 .
} 
Muh Ide Apurines: PRAKTIK PEMERINTAHAN PADA....

Gadjah Mada. ${ }^{3}$ Dijelaskan dalam buku itu bahwa daerah takluk kerajaan Majapahit juga meliputi daerah-daerah di Sulawesi. Negerinegeri di Sulawesi yang disebutkan oleh Prapanca dalam bukunya adalah sebagai berikut:Muwah tanah I Batayan pramuka Batayan len Luwuk tentang Udamakatrayadhi nikanang sanusaspupul Ikangsakasananusanusa Makassar Butun Banggawi Kuni Craliyao mwangi (ng) Selaya Sumba Soto Muar, dst. $^{4}$

Dari informasi Mpu Prapanca tersebut, kita dapat memahami bahwa Buton, sejak zaman Majapahit atau sebelum Islam masuk di daerah Butonsekitar pertengahan abad ke- 16, telah dikenal di daerah luar. Selain kitab Nagarakartagama sebagai sumber sejarah pertama yang menyebut nama Buton, seorang pelaut Portugal Tome Pires juga menyebut nama Buton ketika ia menceritakan pelayarannya di perairan nusantara pada tahun $1512-1515 .{ }^{5}$ Menurutnya, ia berangkat dari Singapura ke Maluku melalui Borneo, Makassar dan Buton. ${ }^{6}$ Informasi ini menunjukan bahwa ketika itu Butontelah dikenal oleh pelaut-pelaut yang melintasi perairan nusantara, termasuk orang asing.

Pengenalan terhadap Buton oleh pihak luar, sebagaimana yang dikemukakan di atas, tidak jelas apakah Buton hanya sebagai suatu pulau ataukah sebagai suatu Kerajaan/Kesultanan yang berdaulat, yang mempunyai sistem pemerintahan tersendiri. Pengenalan dalam arti yang disebut terakhir, dipastikan terjadi pada tahun 1580 . Informasi ini diperoleh dari sumber Ternate yang menyebutkan terjadinya serangan pasukan Kesultanan Ternate ke Kerajaan Buton

\footnotetext{
${ }^{3}$ Bambang Pramudito. 2006. Kitab Negara Kartagama : sejarah tata pemerintahan dan peradilan Keraton Majapahit. Yogyakarta ; gelombang pasang. Hlm. 191.

${ }^{4}$ Seluruh Sulawesi menjadi daerah ke VI kerajaan Majapahit, Yaitu Bantayan(Bantaeng), Luwuk (Luwu), Udamakatraya (Taulaud), Makasar (Makassar), Butun (Buton), Banggawi (Banggai), Kunir (Pulau Kunyit), Selaya (Selayar), Solot (Solor), dan seterusnya.

${ }^{5}$ Armado Corteseo, The Suma Oriental of Tome Pires. Vol. 1, 1944. Hlm 220.

${ }^{6}$ F.s.a. Declerqie. Bijdragen tot de Kennis der Residentie Ternate. 1890. Hlm 154.
}

Jurnal TAPIs Vol. 14 No.02 Juli-Desember 2018 


\section{Muh Ide Apurines: PRAKTIK PEMERINTAHAN PADA....}

untuk menyebarkan agama Islam. ${ }^{7}$ Tidak seperti kerajaan-kerajaan lain yang terdapat di Nusantara dimana jabatan sultan diwariskansecara tunggal turun-temurun. Namun pada sistem pemerintahan Kesultanan Buton, Sultan dipilih berdasarkan berdasarkan satu golongan tertentu (Kaоmu). ${ }^{8}$ Sistem pemilihan ini disebut sebagai demokratis-aristokratis atau sistem pemilihan terbatas. dengan calon yang disiapkan oleh golongan kaomu dengan tiga cabang keluarga yangdisebut Kamboru-Mboru Talu Palena(tiga cabang fraksi partai). ${ }^{9}$ Adapun denganadanya pembagian kekuasaan (power sharing) di Kesultanan Buton antara eksekutif (Sara Pangka), legislatif (Sara Gau) dan, yudikatif (Sara Bhitara) yang bertujuan untuk menstabilkan sistem politik di Kesultanan Buton, terdapat juga sistem desentralisasi pusatdaerah, serta adanya kerajaan aliansi dalam Kesultanan Butonatau biasa lebih dikenal sebagai sistem negara federal.

Disamping itu dengan adanya konstitusi tertulis yang telah di hasilkan oleh pemerintahan Kesultanan Buton di masa Sultan keempat. Yakni produk"Undang-Undang Murtabat Tujuh Sara Wolio", 10 yang menjadi landasan bernegara dan memberikan nilai- nilai luhur terhadap masyarakat Buton.Nusantara Indonesia kaya akan sejarah Kerajaan- Kerajaannya, sebagian besar dari sejarah tersebut mencatat bahwa pemerintahan kerajaan tersebut bersifat monarki, menurunkan putra mahkota sebagai pemimpin atau penerus dan praktik monarki lainnya. ${ }^{11}$ Namun diantara sejarah kerajaan tersebut ada diantaranya yang menerapkan bentuk pemerintahan yang mempunyai unsur demokrasi. Bentuk pemerintahan demokrasi tidak begitu populer di era kerajaan nusantara begitu pula kerajaan yang menerapkannya tidak

\footnotetext{
${ }^{7}$ F.s.a. Declerqie. Op. cit. hlm 221.

${ }^{8}$ Kaomu adalah golongan strata pertama dalam wilayah Kesultanan Buton yang diberi hak untuk memimpin pemerintahan (menjadi Sultan).

${ }^{9}$ Kamborumboru artinya tiang, talu artinya tiga, pale artinya potong, dan na yang berarti nya atau menunjuk tempat tertentu

${ }^{10}$ Martabat Tujuh Sara Wolio adalah peraturan perundang-undangan Kesultanan Buton yang mengatur adat ataupun hukum di buton yang berlandaskan pada murtabat tujuh murni/ Sara Patagunaa beserta ajaran tasawuf.

${ }^{11}$ Purwadi. 2009. Sejarah sastra jawa klasik. Yogyakarta; Panji Pustaka. Hlm 28
}

Jurnal TAPIs Vol. 14 No.02 Juli-Desember 2018 


\section{Muh Ide Apurines: PRAKTIK PEMERINTAHAN PADA....}

begitu populer di buku sejarah yang kita baca. Dari sedikit gambaran latar belakang tersebut penelitian ini kemudian dimaksudkan untuk mengidentifikasi kemudian menganalisis bentuk praktik pemerintahan yang berlangsung di Kesultanan Buton pada tahun 1540-1960 Masehi.

\section{Pembahasan}

Dalam buku The World Alamanac and Book of Fact 2013, jumlah negara di dunia terhitung sebanyak 196. Dengan jumlah negara yang begitu banyak, beberapa negara mempunyai pengaturan pemerintahan yang serupa tetapi ada juga yang berbeda satu sama lain. Dengan demikian untuk menilai bentuk pemerintahan suatu negara paling tidak dengan beberapa tipologi dasar pemerintahan, baik yang dikemukakan oleh Plato, Aristoteles, Polybius, Machiavelli, Montesquieu dan lain-lain, dan dari hal tersebutlah peneliti mengelompokan ada empat jenis pemerintahan:

1. Pemerintahan Monarki (pemerintahan oleh satu orang), Negara yang berbentuk monarki di kepalai oleh seorang raja. Sistem pemerintahan kerajaan pada umumnya, menggunakan sistem pemerintahan terpusat. Kontinuitas kepemimpinannya bersifat turun temurun. Raja dianjurkan mempunyai sifat-sifat ideal yakni adil, murah hati, bijaksana, dan mampu menjaga keamanan serta ketentraman negaranya. Sifat ideal semacam ini adalah syarat universal bagi seorang raja di segala tempat. Sistem pemerintahan kerajaan biasanya menggunakan konsep religi ataupun keagamaan untuk menyatukan orientasi keseluruhan warganya. ${ }^{12}$ Hampir seluruh sistem pemerintahan kerajaan yang ada di asia termasuk Kerajaan Buton di pengaruhi oleh ajaran Hindu Budha.

2. Pemerintahan Aristokrasi, merupakan pemerintahan oleh sekelompok elit masyarakat yang mempunyai status sosial, kekayaan dan kekuasaan politik yang besar, bentuk ini dalam

\footnotetext{
${ }^{12}$ Ensiklopedi.Nasional Indonesia. 1990/1991. Jakarta. Cipta Adi Pustaka. Hlm 57
} 
Muh Ide Apurines: PRAKTIK PEMERINTAHAN PADA....

model pemerintahannya menggunakan sistem warisan dan terpusat pada sekelompok elit tertentu, keberuntungan-keberuntungan ini dinikmati oleh satu generasi ke generasi aristokrat yang lain. Status, kekuasaan dan kekayaan diwariskan

3. Oligarki (pemerintahan oleh sedikit orang yang tak bergelar, militer atau sipil) pemerintahan oleh suatu minoritas dalam masyarakat, suatu minoritas yang tidak perlu dibedakan oleh gelar aristokrasi bentuk pemerintahan atau hak istimewa, biasanya dipegang oleh elit-elit kecildaerah.

4. Pemerintahan Demokrasi, (bentuk pemerintahan yang ditentukan oleh banyak orang) sistem pemerintahannya menggunakan sistem pemerintahan kerakyatan. Dalam sistem politiknya seorang pemimpin dipilih oleh rakyat baik langsung maupun perwakilan. Dalam bentuk pemerintahan ini semua kelas dapat berpartisipasi dalam proses pemerintahan. Suara semua kelas sama penting dan dapat di dengar, bentuk pemerintahan ini akan berjalan maksimal apabila keseimbangan antarkelas bisa tercapai. Bentuk pemerintahan demokrasi sendiri telah hadir dalam masa pemerintahanKesultanan Butonterlihat dari proses pemerintahan yang dijalankan akan tetapi demokrasinya murni versi Kesultanan Buton tidak sesempurna dengan demokrasi prosedural yang di kemukakan oleh Robert A.Dahl.

\section{Teori Demokrasi Robert Dhal}

Robert Dahl merumuskan sebuah ide mengenai tatanan politik yang disebut Polyarchy. Polyarchy merupakan istilah yang dikemukan oleh Dahl untuk mengganti kata demokrasi. Bagi Dahl, demokrasi mengandung dua demensi -kontestasi dan partisipasi. Karena menekankan dua demensi ini maka konsep demokrasi ini sering disebut demokrasi minimalis. Dalam melihat bagaimana demokrasi bekerja cukup dilakukan dengan dua ukuran minimal:

1. seberapa tinggi tingkat kontestasi, kompetisi atau oposisi yang memungkinkan (Liberalisasi).

2. seberapa banyak warganegara yang memperoleh kesempatan berpartisipasi dalam kompetisi politik itu(Inclusiveness).

Jurnal TAPIs Vol. 14 No.02 Juli-Desember 2018 


\section{Muh Ide Apurines: PRAKTIK PEMERINTAHAN PADA....}

Berdasarkan dua demensi tersebut, Dahl membuat tipologi empat sistem politik: hegemoni tertutup (kompetisi dan partisipasi sama-sama rendah); oligarki kompetitif (kompetisi tinggi tetapi partisipasi rendah) ; hegemoni inklusif (partisipasi tinggi-kompetisi rendah) dan Poliarki (partisipasi dan kompetisi tinggi). Kenyataan yang membuktikan bahwa demokrasi ini telah memiliki sejarah demikian panjang benar-benar telah menimbulkan kekacauan dan perbedaan pendapat, karena demokrasi itu mempunyai makna yang berbeda-beda bagi orang yang berbeda- beda, pada waktu dan tempat yang berbeda-beda pula. Dalam periode yang panjang dalam sejarah manusia, demokrasi telah menghilang dalam praktek, dan hanya menjadi sebuah gagasan ataupun kenangan dikalangan sejumlah kecil orang tertentu saja. Sampai dua abad yang terakhir ini saja, dalam sepuluh generasi, sedikit sekali sejarahyang memperlihatkan contoh-contoh demokrasi yang sesungguhnya. ${ }^{13}$

Demokrasi menggambarkan sistem pemerintahan yang berasaskan bahwa kedaulatan berada ditangan rakyat. Abraham Lincoln dalam pidato Gettysburg mendefinisikan demokrasi pemerintahan dari rakyat, oleh rakyat, dan untuk rakyat (government of the people, by the people, and for the people). Rakyat mempunyai kekuasaan mutlak terhadap sebuah pemerintahan dalam negara, rakyat mempunyai kedaulatan tertinggi dalam sebuah negara. Demokrasi memungkinkan semua rakyat untuk ikut andil dalam pembuatan, perumusan dan pengembangan hukum baik itu secara langsung maupun secara tak langsung (perwakilan). Suatu negara yang memiliki sistem pemerintahan demokrasi akan sangat berbeda dibandingkan dengan pemerintahan yang bentuknya monarki.

Gagasan mengenai demokrasi sangatlah luas, untuk mengenali apakah bentuk pemerintahan suatu negara tersebut berbentuk demokrasi atau tidak, Dahl, ${ }^{14}$ telah merumuskan lima kriteria untuk mencapai bentuk pemerintahan demokrasi kriteria tersebutyaitu:

\footnotetext{
${ }^{13}$ Robert A. Dahl. 2001. Perihal Demokrasi. Jakarta. Yayasan Obor Indonesia. hlm 40

${ }^{14}$ Robert A. Dahl. Op.cit. hlm 52
}

Jurnal TAPIs Vol. 14 No.02 Juli-Desember 2018 
Muh Ide Apurines: PRAKTIK PEMERINTAHAN PADA....

1. Partisipasi efektif. Sebelum sebuah kebijakan digunakan oleh kelompok, seluruh anggota harus mempunyai kesempatan yang sama dan efektif untuk membuat sebuah gagasan atau ide yang dapat diketahui oleh anggota-anggota lainnya sebagaimana kebijakan itudibuat.

2. Persamaan suara. Ketika tiba saatdibuatnya keputusan mengenai kebijakan tersebut, maka setiap anggota berhak mempunyai kesempatan yang sama untuk memberikan suara dan seluruh suara harus dihitungsama

3. Pemahaman yang cerah. Dalam batas waktu yang rasional setiap anggota berhak mempunyai kesempatan yang sama untuk mempelajari kebijakan-kebijakan alternative yang relevan dan konsekuensi-konsekuensi yangmungkin

4. Pengawasan agenda. Setiap anggota berhak mempunyai kesempatan ekslusif untuk memutuskan bagaimana dan apa permasalahan yang dibahas dalam agenda. Jadi proses demokrasi yang dibutuhkan oleh tiga kriteria sebelumnya tidak pernah tertutup. Berbagai kebijakan kelompok tersebut selalu terbuka untuk dapat diubah oleh para anggotanya, jika merakamenginginkannya.

5. Pencakupan orang dewasa. Semua, atau paling tidak sebagian besar, orang dewasa yang menjadi penduduk tetap seharusnya memiliki hak kewarganegaraan penuh, yang ditunjukkan oleh empat kriteriasebelumnya

\section{Bentuk Pemerintahan Kerajaan Buton}

Sistem pemerintahan dimasa Kerajaan Buton berbentuk Monarki karena dikuasai oleh dinasti Wa Kaka yangsecara turun temurun berkuasa di Kerajaan Buton. Pada masa kerajaan ini pula dari raja pertama hingga raja ke 5 tidak ditemukan tanda-tanda pengaruh islam bahkan yang tampak adalah pengaruh kebudayaan Hindu yang salah satunya terdapat pada nama-nama raja. Disamping itu 


\section{Muh Ide Apurines: PRAKTIK PEMERINTAHAN PADA....}

dalam aspek keyakinan juga dijumpai faham "reinkarnasi". ${ }^{15}$ Paham ini hingga saat ini masih diyakini oleh masyarakat Buton, prakteknya dapat di lihat pada saat kelahiran. Anak yang lahir mirip dengan anak yang telah meninggal maka anak itu dikatakan sebagai roh dari saudaranya tersebut. keyakinan ini diprediksi sebagai salah satu pengaruh budaya Hindu.

Dalam masa kerajaan Buton menggunakan bentuk pemerintahan Monarki hal ini terlihat dalam pergantian raja scara turun temurun, yaitu seorang raja yang mangkat atau mengundurkan diri diganti oleh anaknya dan bagi raja yang tidak mempunyai keturunan akan digantikan oleh keponakan, yang telah dijadikan anak angkat. Struktur Pemerintahan dimasa Kerajaan Buton pertama Wa Kaka:

1. Raja

2. Majelis sara juga sebagai menteri koordinator yang beranggotakan Mia Patamiana, bertugas mengkoordinir tiap-tiap kelompok dalamlimbonya.

3. Pemimpin tinggi angkatan perang, juga bertugas sebagai duta dalam hubungan luar negeri. pada masa kerajaan jabatan ini pertama kali dijabat oleh Sibatara dan sekaligus sebagaipenasehatraja.

4. Menteri khusus daerah seberang dan perluasan wilayah menteri ini juga menjabat sebagai komando pasukan khusus pengawal istana dipimpin oleh Kaudoro dan Sangiariana. Pada masa pemerintahan Bataraguru struktur pemerintahan kerajaan bertambah yaitu dengan adanya jabatan baru seorang Sapati yang bertugas membantu raja dalam pelaksanaan pemerintahan di pusat kerajaan dimasa modern sering dikenal dengan perdana menteri. Pada masa pemerintahan Raja Tuarade juga terjadi pertambahan jabatan yaitu

\footnotetext{
${ }^{15}$ Schoorl. Op; cit hlm 124, dalam buku tersebut di temukan adanya pengaruh kepercayaan Hindu dalam Kerajaan Buton di masa lampau terlihat dari adanya keperayaan terhadap rengkarnasi.
}

Jurnal TAPIs Vol. 14 No.02 Juli-Desember 2018 


\section{Muh Ide Apurines: PRAKTIK PEMERINTAHAN PADA....}

jabatan kanepulu yang fungsinya membantu Sapati/wakil dari sapati. Hal ini disebabkan makin komplitnya permasalahan pemerintahan karena bertambahnya wilayah kerajaan Buton. ${ }^{16}$ Bentuk pemerintahan monarki berlangsung kurang lebih dua setengah abad lamanya dan baru berakhir setelah Buton menerima ajaran islam sebagai agama kerajaan. Perlu dijelaskan bawa sebelum bentuk pemerintahan monarki pemerintahan Buton dimasa sebelum kerajaan masih berbentuk aristokrasi. Pemerintahan kerajan berakhir setelah raja ke enam Lakinaponto memeluk agama islam dan berganti menjadi Sultan Buton pertama.

\section{Bentuk Pemerintahan di Masa Kesultanan}

Islam diterima sebagai agama kerajaan Buton pada maasa pemerintahan raja keenam (Lakinaponto) pada tahun 948 Hijriah atau lebih kurang $1538 \mathrm{M}$. setelah memeluk islam Lakinaponto dilantik menjadi sultan dengan gelar Qa'im ad-din, (138-1584) yang ketika beliau dilantik menjadi Sultan lebih dikenal dengan nama Murhum. Menurut riwayatnya bahwa pada masa raja Buton lakilaponto. Datanglah Syekh Abd Wahid bersama istrinya Waode Solo dan anaknya, ledi penghulu, ia dianggap orang keramat turunan Sayyid Mekah, cucu nabi Muhammad. Atas ajakan Laki Laponto bersama menetrinya memeluk islam yaitu pada hari senin, 1 Ramadhan $948 \mathrm{H}$. Laki Laponto di lantik menjadi sultan oleh Syekh dengan nama kehormatan Qa'im ad-din al Khalifah al-khamis. ${ }^{17}$

Beralihnya sistem pemerintahan dari kerajaan ke kesultanan, mempengaruhi pola kehidupan sosial budaya masyarakat. Perubahan ini dapat dilihat pada falsafah hidup masyarakat Buton setelah memeluk agama islam yaitu "binci binciki kuli".Falsafah ini mengandung makna kita sebagai sesama manusia harus mempunyai empati yang tinggi (jika anda merasa sakit dan di hina orang begitu

\footnotetext{
${ }^{16}$ Hambali. 1990. Sistem Pemerintahan Kesultanan Buton “Ketatanegaraan”. Skripsi. Hlm 55.

${ }^{17}$ Zahari. 1977. Sejarah dan adat fiy darul butuni jilid, I,ii,iii. Jakarta. Depdikbud. Hlm 10.
}

Jurnal TAPIs Vol. 14 No.02 Juli-Desember 2018 


\section{Muh Ide Apurines: PRAKTIK PEMERINTAHAN PADA....}

pula perasaan orang ketika anda menghinanya). Di era transisi pengaruh antara kerajaan ke kesultananan ajaran islam boleh dikatakan dalam tahap sosialisasi ajaran islam diseluruh wilayah kekuasaannya. Pengaruh budaya islam yang lain dapat dilihat pula pada falsafah perjuangan masyarakt Buton yaitu "biar hancur harta, negara, dan pemerintah asalkan agama selamat". 18

Di bidang politik telah terjadi pula perubahan tata cara pemilihan pejabat mulai dari sultan pertama sampai sultan ketiga yakni : Lakinaponto (153-184) Latumparasi (1584- 1591) dan masa pemerintahan sultan ketiga Lasangaji (1591-1597) perkembangan islam belum begitu menonjol. ${ }^{19}$ Dan dimasa pemerintahan sultan pertama hingga ketiga masih menggunakan sistem monarki absolute dikarenakan dalam pemilihan Sultannya masih mewariskan putra mahkota yang saling turun temurun. Tata pemilihan sultannya pun tetap menggunakan tradisi yang diturunkan dimasa Kerajaan, dan ajaran Konstitusi Kesultanan Buton (Murtabat Tujuh) belum terbentuk.

Dari perubahan-perubahan fundamental tersebut, terbentuknya konstitusi undang- undang Murtabat Tujuh menjadi fondasi perubahan yang mendasar dalam struktur pemerintahan, hukum, maupun adat istiadat masyarakat Buton. semasa di terapkannya undang-undang tersbut Sultan dalam menjalankan tugasnya selalu menganjurkan serta menegaskan pada masyarakatnya maupun pemerintahannya agar bertindak berdasarkan norma dan petunjuk yang jelas, sesui dalam undang-undang Murtabat Tujuh bukan lagi berdasarkan inisiasi perorangan ataupun kelompok. ${ }^{20}$ Kebijakannya selalu dijiwai dengan nafas keislaman yang baik itu kebijakan yang menyadarkan bahwa ada keterkaitan dengan politik, sosial budaya, ekonomi, maupun pertahanan dan keamanan. Dalam memutuskan sesuatu, sultan selalu menekankan agar melalui proses musyawarah mufakat atau dalam ajaran islam lebih dikenal dengan nama Syura.

Tujuh.

${ }^{18}$ Falsafah dalam hikayat Negeri Buton yang tertuang juga dalam Murtabat

${ }^{19}$ Lihat pada Dokument DPRD Sultra 1977-1982 hlm. 187.

${ }^{20}$ Zahari. Op,cit. hlm 14

Jurnal TAPIs Vol. 14 No.02 Juli-Desember 2018 


\section{Muh Ide Apurines: PRAKTIK PEMERINTAHAN PADA....}

Kepimimpinan Sultan ke-4 selalu mempraktekkan nilai-nilai keadilan, ekualitas, kebebasan, penegakan hukun, jaminan kesejahteraan bagi semua warga serta perlindungan terhadap kaum minoritas. Pada prinsipnya menyadarkan yang dipimpinnya bahwa semua manusia sama.

Dalam ajaran Islam ditegaskan bahwa, pada dasarnya manusia memiliki nilai kemanusian yang sama, tidak ada yang lebih mulia dari yang lain yang membedakan mereka adalah ketakwaannya terhadap allah swt, yakni bertanggung jawab menjalankan kewajiban pada Allah dan sesame manusia. ${ }^{21}$ Dalam penyusunan undang-undang Murbatat Tujuh, Dayanu Ikhsanuddin mendapat bantuan dana sehat dalam bidang agama dari Syeikh Said Muhammad seorang berkebangsaan Arab. Sultan ke-4 dalam masa pemerintahannya mengadakan reformasi yang progresif. Secara hirarki sistem perundang- undangan di Kesultanan Buton, pada masa Sultan ke-4 tersusun sebagi berikut:

a. Syara, yakni Undang-undang dasar atau MurtabatTujuh

b. Tuturaka peraturan pemerintahKesutanan

c. Pitara pedoman dalam mengadili atau memutuskan suatuperkara

d. Gau masalah-masalah yang berhubungan denganpolitik

Berdasarkan hirarki sistim perundang-udangan tersebut, undang-undang Murtabat Tujuh menempati posisi teratas. ${ }^{22}$ Dimasa pemerintahannya Sultan ke-4 telah membentuk sistem pemeritahan yang modern pada masanya dan struktur pemerintahannya sebagai berikut:

a. Sultan sebagai kepalapemerintahan

b. Sapati sebagai perdanamenteri

\footnotetext{
${ }^{21} 21$ tertuang dalam Al-Quran, Surah Q.S almujarad 13

${ }^{22}$ Saidi. 2001. Studi Sosiologi Kultural Dan Historis Tentang Dasar-Dasar Adat Dan Budya Masyarakat Buton. Bau-bau. Hasil penelitian Inventarisasi adat dan budaya masyarakat Buton. hlm 56
}

Jurnal TAPIs Vol. 14 No.02 Juli-Desember 2018 
Muh Ide Apurines: PRAKTIK PEMERINTAHAN PADA....

c. Sio Limbona sebagai Legislatif atau saat ini biasa di sebut DPR

d. Kenepulu sebagai sekretaris negara merangkap hakimagung

e. Kapitalao menteri pertahanan

f. Bonto Ogena terbagi menjadi dua, Bonto Ogena matanaeo dan Bonto Ogena Sunaeo (pejabat tinggi negara yang memiliki multi tugas) lima jabatan diatas biasa disebut Pangka(kabinet/menteri)

g. Bonto Inunca

h. Bonto Bonto lancinakanjawari

i. Bobato

j. Jurubahasa

k. Sabandara

1. Tolombo

m. Pangalasa

Struktur pemerintahan dalam bidang agama yaitu; Lakina Agama, Imam, Khatib, Moji, Mokimu, dan Bisa. Implementasi sistem pemerintahan Undang-undang Murtabat Tujuh menjalankan praktek kepemimpinan Islam, menjadi fondasi dan suri tauladan pada masa pemerintahan Sultan-sultan berikutnya. Murtabat Tujuh menjadi tonggak perubahan yang mendasar dalam struktur pemerintahan, hukum maupun adat istiadat masyarakat Buton

\section{Praktek Demokrasi Pada KesultananButon}

Tidak dapat dipungkiri bahwa setiap negara memiliki bentuk dan sistem pemerintahan yang sistemnya disesuaikan dengan kebutuhan masyarakat dan negara. Demikian halnya dengan Negara Kesultanan Buton, bentuk dan sistem pemerintahannya berpedoman pada Murtabat Tujuh Sara Wolio yang di dalam praktik pemerintahannya terdapat unsur demokrasi. Kepala pemerintahan dipimpin oleh seorang Sultan yang dipilih oleh lembagaSiolimbona (legislative). Sistem pemeritahan Kesultanan Buton menggunakan sistem presidensial Sultan bertindak langsung sebagai kepala negara dan kepala pemeritahan, serta bentuk pemerintahan menggunakan monarki konstitusional, dalam praktik penyelenggaraan pemeritahannya terdapat unsur demokrasi.

Jurnal TAPIs Vol. 14 No.02 Juli-Desember 2018 


\section{Muh Ide Apurines: PRAKTIK PEMERINTAHAN PADA....}

\section{Partisipasi efektif dalam KesultananButon}

Partisipasi yang dimaksudkan oleh Robert Dahl dalam sebuah pemerintahan demokrasi yaitu, peran semua lapisan masyarakat untuk turun langsung membahas agenda-agenda yang berkaitan dengan kebijakan, ataupun masalah umum, baik berkaitan dengan politik ataupun kekuasaan. Untuk konteks Kesultanan Buton partisipasi efektif yang dimaksudkan oleh Robert Dahl telah di jalankan ditandai dengan ke ikutsertaan lapisan sosial masyarakat untuk ikut serta dalam membahas sebuah kebijakan umum.

Contoh kongkritnya dalam hal penentuan kebijakan yang menyangkut negara dan masyarakat luas, seorang Sultan tidak dapat memutuskan kebijakan secara sepihak seperti halnya raja-raja. Sistem ini bertujuan untuk meminimalkan bahaya penyelewengan kekuasaan yang dampaknya bisa mengakibatkan tirani. Segala sesuatu yang menyangkut keputusan maupun kebijakan yang akan dikeluarkan oleh pemerintah, dalam hal pelaksanaan kewajiban dan tanggung jawab sebagai aparat negara, diputuskan melalui musyawarah mufakat yang melibatkan seluruh lapisan masyarakat Kesultanan Buton, baik dari jajaran perwakilan pemerintah pusat, pemerintah daerah (Kadie), dan aliansi pemerintahan (Barata) semua dilibatkan serta mempunyai hak yang sama dalam proses musyawarah tersebut.

Beberapa contoh dalam hal peraturan pembagian pajak dalam sebuah kecamatan (Kadie) pihak kesultanan akan meninjau kecamatan tersebut melihat potensi apa yang ada dalam kecamatan tersebut setelah itu menentukan pajak apa yang akan dikenakan oleh kecamatan, tentunya melalui proses tahap musyawarah yang mempertemukan pihak pemerintahan pusat (Sultan dan Siolimbona) dan pihak pemimpin kecamatan (Lakina Dan Bonto) untuk membahas besaran pajak tersebut. Sejalan dengan pandangan Al-Quran yang menegaskan tentang prinsip "syura" (musyawarah) untuk mengatur proses pembuatan keputusan, Al-Quran dengan tegas menyebutkan "semua keputusan mereka diputuskan melalui proses musyawarah

Jurnal TAPIs Vol. 14 No.02 Juli-Desember 2018 


\section{Muh Ide Apurines: PRAKTIK PEMERINTAHAN PADA....}

antara mereka". ${ }^{23}$ Dimaksud dengan urusan mereka adalah bukan urusan perorangan, kelompok ataupun elit tertentu urusan yang dimaksud dalam hal ini yakni "urusan masyarakat pada umumnya" dan milik masyarakat secarakeseluruhan. ${ }^{24}$

\section{Status Sosial dalam Lingkup KesultananButon}

Syarat demokrasi prosedural yang dipaparkan oleh Dahl, mengenai persamaan suara untuk konteks Kesultanan Buton masi terbatas dalam hal partisipasi politik belum menyentuh, kepersamaan hak dalam pekerjaan ataupun status sosial lebih cenderung menempatkan hak yang sesuai dengan proposinya. Kesultanan Buton mempunyai klaster tersendiri untuk pemangku jabatan-jabatan penting dalam pemerintahannya "Stratifikasi masyarakat Buton terjadi tidak lain karena alasan politik. Pada masa pemerintahannya, Dayanu Ikhasanuddin melakukan pertemuan dan sepakat dengan sapati yang saat itu dijabat oleh La Singga dan Kanepulu dijabat oleh La Bula. Petemuan ini didasari atas usul Abdul Wahid, mengingat karena ketiga orang ini mengawini anak dari Abdul Wahid dan untuk mencegah agar tidak terjadi penerus tahta yang hanya keturunan dari Sultan Pertama Hingga yang Ke empat Dayanu Ikhsanuddin (kepemimpinan tahta turun temurun) maka dengan bijak beliau menyarankan kepada ketiga menantunya untuk musyawarah dalam membahas pembagian kekuasaan dan untuk mengantisipasi terjadinya ambisi jabatan dalam menduduki posisi sultan. Sepakatlah ketiga belah pihak bahwahanya keturunan mereka yang berhak menduduki ketiga jabatan tinggi kerajaan, yaitu jabatan, Sultan, Sapati dan Kanepulu."25

Keturunan mereka bertiga inilah yang kemudian dikenal dengan golongan kaomo atau bisa disebut juga Lalaki, dan golongan Walaka berasal dari keturunan para Bonto atau kepala kampong dan

\footnotetext{
${ }^{23}$ Tertuang dalam Al-Quran. Surah As Syura 42;38

${ }^{24}$ Ikram. A. 2001. Katalog Naskah Buton. Jakarta. Yayasan Obor Indonesia. Hlm 10

${ }^{25}$ Hasil Wawancara dengan Mujazi, 12 Oktober 2014
} 


\section{Muh Ide Apurines: PRAKTIK PEMERINTAHAN PADA....}

golongan Papara yaitu golongan yang tidak ada hubungan darah dari kedua golongan tersebut. golongan papara ini adalah masyarakat mendiami Limbo ataupun Kadie. Papara sendiri terbagi atas tiga klaster yaitu; 1) Papara dari keturunan masyarakat asli yang tunduk pada Kesultanan Buton atas kemaunnya sendiri (Papara Kantinale). 2) Papara yang datang dari luar yang tunduk pada Kesultanan Buton karena tawanan perang (Tolubirana). 3) Papara yang datang menyerahkan dirinya dengan tidak melalui perang(Peraka).Sedangkan lapisan masyarakat Buton yang paling terbawah adalah Batua (budak) yang dilahirkan dari ibu bapaknya yang seorang budak juga. Jika ibunya saja yang budak, maka anaknya tidak menjadi budak karena dalam sistem kekerabatan/kekeluargaan masyarakat Buton menggunakan sistem patriaki. Kategori dalam budak sendiri terdapat tiga kategori yaitu:

1. Orang yang tunduk dibawah kekuasaan kerajaan dengan paksa dalam adat disebut bente

2. Musuh kerajaan yang kalah dalampeperangan

3. Dan orang luar kerajaan yang dirampas dan dijual kepada golongan kaomu danwalaka.

\section{Tanggung jawab Politik dalam KesultananButon}

Hak-hak politik eksekutif (Sultan) diawasi langsung oleh badan "Siolimbona" (legislative). Sultan dalam bertindak harus melalui persetujuan aparat negara Kesultanan (Pangka) dan persetujuan dari lembaga Sio Limbona. Sistem pengawasan dewan Sioliombona terhadap sultan, bersifat langsung dan berkesinambungan (proaktif). Jadi tidak harus menunggu laporan dari seorang rakyat atau karena adanya aksi demonstrasi baru lembaga eksekutif turun gunung. Tindakan-tindakan seorang Sultan maupun pejabat negara disesuaikan dengan budaya bangsa, kepentingan negara dan kepentingan masyarakat yang dipimpinnya, tidak berdasarkan kepentingan kelompok atau preferensi perorangan. Hal ini didasarkan oleh pasal

${ }^{26}$ Siolimbona adalah jabatan yang hanya bisa di tempati oleh golongan walaka, berfungsi sebagai dewan penasehat tertinggi di kesultanan Buton serta sebagai penyeleksi dan pelantik calon sultan.

Jurnal TAPIs Vol. 14 No.02 Juli-Desember 2018 


\title{
Muh Ide Apurines: PRAKTIK PEMERINTAHAN PADA....
}

\author{
1,3 dan 4 undang-undang Murtabat Tujuh. ${ }^{27}$ \\ Pola rekruitmen pemimpin dalam sistem dan bentuk
} pemerintahan Kesultanan Buton bersiat tidak langsung. Masyarakat atau rakyat menyalurkan aspirasinya lewat dewan Siolimbona, dewan inilah yang memilih seorang Sultan. Dalam pelaksanaan pemeritahan sultan bertanggung jawab langsung oleh rakyat yang dipimpinya. Sedangkan rekruitmen pejabat lainnya, tata cara pengangkatan berdasarkan pengalaman dibidang yang akan dijabat ataupun memiliki pengaetahuan yang cukup sesui jabatan yang di emban. Selain pengetahuan dalam rekrutman di utamakan pola model moralitas

Disamping hal tersebut, pengangkatan sultan ataupun pejabat pemeritahan negara harus mempunyai syarat yang tertera pada pasal 3 , 5 , dan 6 Undang-undang Martabat Tujuh. ${ }^{28}$ Khusus dengan Siolimbona, sistem pengangkatannya melalui kalangan Kaomu. Pejabat negara kesultanan, selain sapati, dalam melaksanakan roda pemerintahannya wajib bertanggung jawab langsung kepada sultan. Perlu dijelaskan bahwa walaupun sapati dalam sistem pemerintahan adalah sebagai pemimpin dalam melaksanakan pemerintahan, dalam menjalankan tugasnya tidak bertanggung jawab terhadap sultan tetapi bertanggung jawab terhadap dewanSiolimbona.

Jika dilihat dari tata cara pengangkatan para pejabat tersebut keahlian dan kesempurnaan batinlah yang diutamakan. Tidak seperti halnya era modern ini pejabat atau pemimpin yang duduk dalam pemerintahan ada indikasi tidak berdasarkan keahlian. Adapun pejabat yang ditempatkan sesuai keahliannya itu hanya sedikit ataupun secara kebetualan. Dari beratus-ratus jabatan kemungkinan hanya terdapat satu atau dua orang pejabat yang sesuai dengan keahliannya. Dewasa

\footnotetext{
${ }^{27}$ Pasal,1,3,4 dalam pasal pertama mempunyai intisari mngenai pokok adat berlandaskan perikemanusiaan, pasal ketiga mengenai sifat sifat dasar seorang pemimpin, dan pasal keempat yang mejelaskan intisari pokok-pokok adat Kesultanan Buton.

${ }^{28}$ Pasal 3 menjelaskan sifat-sifat yang diwajibkan atas pemimpin masyarakat, Pasal 5 menjelaskan 7 sifat tuhan yang harus di teladani, Pasal 6 susunan dalam pembentukan sarah pada dan pangkat-pangkat.
}

Jurnal TAPIs Vol. 14 No.02 Juli-Desember 2018 


\section{Muh Ide Apurines: PRAKTIK PEMERINTAHAN PADA....}

ini dalam rekruitmen pejabat ada indikasi faktor moralitas bukan merupakan hal yang sangat prinsipal lagi. Ini dapat dilihat pada beberapa pejabat negara yang terindikasi perbuatan korupsi ataupun amoral yang berkelebihan.

\section{Pengawasan Agenda dalam Ketersedian Lembaga Negara di Kesultanan Buton}

Kesultanan Buton dalam penerapan pemerintahannya menganut sistem pemisahan kekuasaan ke dalam cabang-cabang yang luas. Hal ini di dasari oleh pasal 1 UU Murtabat Tujuh. ${ }^{29}$ Cabangcabang tersebut terdiri dari; eksekutif (Sultan), Legislatif (Siolimbona) dan yudikatif (Kenepulu), hal ini sejalan dengan teori pembagian kekuasaan yang dikemukakan oleh Montesquieu lebih dikenal dengan Teori trias politika, yakni legislatif, eksekutif, dan yudikatif, untuk sistem pemerintahannya menganut sistem presidensial dimana raja sebagai kepala negara dan kepala pemerintahan. Pemerintahan Kesultanan Butondalam menjalankan tugas negara dibantu oleh jajaran birokrasi yang berada pada wilayah ibukota kesultanan maupun birokrasi yang bertugas diluar ibukota.

Pemerintahan Kesultanan Buton diatur oleh satu konstitusi tertulis yang oleh masyarakat Buton dikenal dengan undang-undang Murtabat Tujuh Sara Wolio. Dalam konstitusi Undang-undang Murtabat Tujuh, implementasi pemerintahan menggunakan sistem "Resposible Government" (pemerintahan yang bertanggung jawab). Negara menggunakan prinsip pemisahan lembaga dan pemisahan daerah kekuasaan dengan tujuan untuk menghindari kekuasaan yang tumpah tindi (separation of powers). Pembagian wilayah pemerintahan terdiri dari wilayah pusat pemerintahan yang berada di ibukota kesultanan, wilayah Barata, berada di daerah-daerah Barata dan wilayah Kadie berada di daerah-daerah Kadie. Masing-masing wilayah tersebut dipimpin oleh seorang Bonto atau Lakina.

Pemilihan kepala wilayah, baik daerah Barata maupun Kadie,

\footnotetext{
${ }^{29}$ Pasal 1 Undang-undang Murtabat Tujuh yang menjelaskan pokok adat berdasarkan falsafah
}

Jurnal TAPIs Vol. 14 No.02 Juli-Desember 2018 


\section{Muh Ide Apurines: PRAKTIK PEMERINTAHAN PADA....}

dipilih langsung oleh masyarakatnya tanpa campur tangan pemerintah pusat. Kebijakan dan urusan rumah tangga daerah Barata diserahkan sepenuhnya kepada daerah Barata (otonomi penuh). Khusus daerah Kadiedalam perihal pemimpin apabila salah satu Kadie tidak mempunyai seorang calon pemipin, seorang Bonto yang bertugas mengontrol pemerintahan di daerah Kadie diperbolehkan menjadi pemimpin Kadie. Dengan persetujuan Sultan atas permintaan masyarakat setempat. Daerah Barata di samping mempunyai hak otonom, juga merupakan daerah pertahanan keamanan negara Kesultanan. Apabila ada penyerangan dari luar, daerahBaratalah yang mengadakan perlawanan terlebih dahulu. Kapitalao akan mengeluarkan kebijakan (bantuan) apabila Barata yang bersangkutan meminta batuan. Tanpa permintaan dari Barata, kapitalao tidak berhak ikut campur dalam kebijakan daerah Barata walaupun kapitalao dalam negara modern adalah seorang menteri pertahanan dan keamanan. Proses pemilhan pemimpin setiap kesultanan di nusantara mempunyai tahapan yang berbeda-beda baik dari proses penjaringan sultan dan tata cara pelantikannya. Untuk Kesultanan Buton terdiri dari beberapa tahapan; pertama melalui sistem kepartaian, kedua tahap Fali, (setelah memperoleh calon dari tiap partai), ketiga tahap Penetapan calon Sultan, dan keempat.

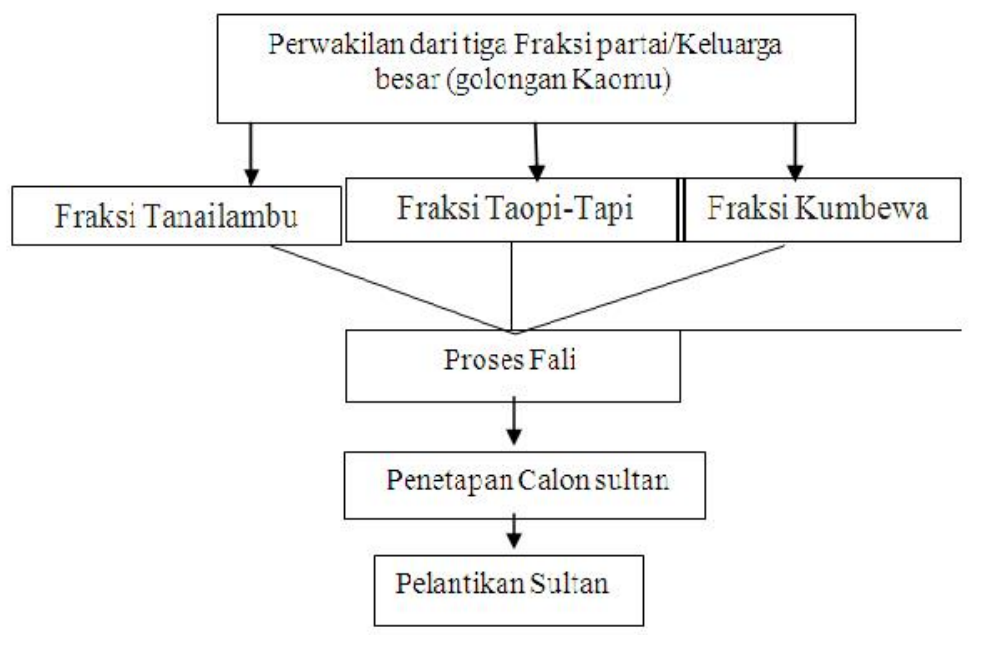

Jurnal TAPIs Vol. 14 No.02 Juli-Desember 2018 


\title{
Muh Ide Apurines: PRAKTIK PEMERINTAHAN PADA....
}

\author{
Gambar 1. Tahapan Pemilihan Sultan
}

\section{Keistimewaan Konstitusi Murtabat Tujuh}

Berbicara tentang keistimewaan suatu konstitusi berarti berbicara pula tentang sejauh mana konstitusi itu dapat mensejahterakan dan menciptakan kedamaian dalam masyarakatnya. Semua konstitusi mempunyai keistimawaan. Keistimawaan setiap undang-undang dapat dilihat pada seberapa konstribusi Undangundang tersebut dapat menjamin ketentraman, keadilan dan kenyamanan masyarakatnya keistimewaan undang- undang Murtabat Tujuh:

Pertama, sebagai dasar ilmu dan sumber hukum dalam ketatanegaraan yang mengambil hikmat Al-Quran dan hadits yang dipersatukan dalam kesatuan sistem yaitu sistem pemerintahan, berbangsa dan bernegara. Nilai-nilai Murtabat tujuh bersiat universal dengan kata lain nilai yang terkandung dalam murtabat Tujuh dapat diterapkan kapan saja dan dimana saja. Jika dilihat dari letak geografis yang beranekaragam suku dan budaya serta bahasa yang berbeda di Kesultanan Buton, dapat dikatakan sebagai Nusantara mini. Kendatipun masyarakat sangat plural dan memiliki bahasa yang beraneka ragam, nilai- nilai Murtabat Tujuh dapat menyatukan seluruh lapisan masyarakat di Kesultanan Buton. ${ }^{30}$ nilai yang bersifat universal tersebut bisa dilihat pada falsafah yang terkandung dalam Murtabat Tujuhyaitu "Bincci-bhinciki kuli" (nilai rasa empati) dalam pemaknaannya bisa diartikan mencubit kulit sendiri sebelum mencubit kulit orang lain maksud dari falsafah tersebut adalah mengenai rasa empati yang tinggi serta rasa saling menghormati dan menghargai.

Nilai rasa tersebut dapat mempersatukan negara Kesultanan Buton. Binci-bhinciki kuli dalam pergaulan sehari-hari dimanifeestikan dalam bentuk saling menyayangi satu sama lain,

\footnotetext{
${ }^{30}$ Abubakar, Op.cit. hlm 81
}

Jurnal TAPIs Vol. 14 No.02 Juli-Desember 2018 


\section{Muh Ide Apurines: PRAKTIK PEMERINTAHAN PADA....}

saling menghormati satu sama lain, saling memelihara satu sama lain dan saling taat menaati. Taat menaati bukan karena kedudukan atau jabatan seirang sehingga ia ditaati tetapi karena setiap manusi memiliki hak lebih yaitu hak asasi. Hak ini tidak boleh dilanggar oleh siapapun. ${ }^{31}$ Empat dasar inilah yang ditrapkan oleh masyarakat Buton dalam kehidupan berbangsa danbernegara. Penerapan nilai-nilai Murtabat tujuh tersebut dapat menciptakan akhlak yang baik dan tidak menyinggung perasaan orang lain. Dengan terciptanya akhlak yang baik, masing-masing orang atau masyarakat akan bekerja sesuai aturan yang dikehendaki oleh semua pihak. Dengan demikian kerukunan, kedamaian dan kesejahteraan yang diinginkan dapat terwujudkan.

Kedua, undang-undang Murtabat tujuh digali dari ilmu Tasawuf khususnya ilmu kebatinan yang mengadopsi dari Murtabat Tujuh ersi Ibnu Arabi dan digali dari dua puluh sifat Allah SWT melalui jalan ijtihhad sehingga mampu bertahan dalam segala zaman. Nilai yang terkandung dalam undang-undang Murtabat Tujuh tiada lain adalah memanusiakan manusia, menjadi manusia Khaliffatullah, sejahtera Zahir maupun bathin. Oleh sebab itu, rakyatnya patuh dan tunduk terhadap pemerintah melalui hokum adat. Seseorang yang tidak beradap dan beradat, jelas sekali orang itu menghianati agamanya yang dipanutinya. Sehingga pada jamanya orang akan merasa malu kalau dikatakan tidak beradat dan lebih baik mati daripada dikatakan demikian.

Ketiga, nilai-nilai Murtabat Tujuh bersifat horizontal dan vertical, Murtabat Tujuh menjamin dan mengatur kehidupan masyarakat bukan hanya kehidupan dunia tapi juga kehidupan akhirat. Nilai-nilai yang terkandung didalamnya adalah:

1. Nilai agama yang mendalam

2. Nilai kemanusiaan yang tinggi

3. Nilai sosial yang kokoh

\footnotetext{
${ }^{31}$ Pasal 3 undang-undang Murtabat Tujuh. Dalam pasal ini berisi mengenai sifat-sifat yang diwajibkan oleh seorang pemimpin untuk memimpin masyarakatnya
}

Jurnal TAPIs Vol. 14 No.02 Juli-Desember 2018 


\section{Muh Ide Apurines: PRAKTIK PEMERINTAHAN PADA....}

4. Nilai persatuan yang kental

5. Nilai kebangsaan yang tinggi

6. Nilai kejujuran yangt ransparan.

Tidak ada sendi kehidupan, pengetahuan dan peradaban manusia yang tak tersentuh gairah pemikiran politik. Politik digunakan untuk beragam makna. "politik bisa berarti seperangkat hipotesa mengenai proses atau institusi pemerintahan, atau juga bisa merujuk pada prinsip-prinsip dan norma-norma yang mengontrol perilaku politik. Aristoteles sepakat dengan Plato bahwa manusia adalah hewan politik yang bisa memenuhi wataknya hanya dalam polis; bahwa negara adalah institusi moral yang ada untuk membantu manusia mencapai kesempurnaanya; bahwa negara yang benar berupaya menciptakan kesejahteraan bagi semua dan bukan hanya untuk kebaikansekelompok saja. ${ }^{32}$

Politik dalam Kesultan Buton disebut Gau/musyawarah. Permulaan segala peraturan negara berasal dari pemufakatan yang tidak lampau keputusan tetang negara atau hasil proses politik di Kesultan Buton tercapai dengan baik melaui proses pemufakatan bersama. Nilai Murtabt Tujuh yang berhubungan dengan politik adalah nilai- nilai pengabdian maasyarakat terhadap negara yaitu;

1. Ainda-indamo aurata sumanamo karo, (kepentingan diriorang banyak lebih utama dari harta benda), adalah wujud dari pengabdian dan pengorabanan rakyat terhadap sesame warga negara dan umat manusia, harta benda yang dimiliki seberapapun harganya rela dikorbankan demi keselamatan diri atau orang banyak. Apalah artinya harta kalau diri atau masyarakat lain tidak merasa aman dan nyaman, harta tidak mempunyai nilai, justru harta itu akan menimbulkan kecemburuan masyarakat lain yang akan mengakibatkan persatuan menjadi renggang. Sehingga apabila kerenggangan ini terjadi persatuan untuk mencapai tujuan bersama negara untuk mewujudkan keidupan yang sejahterah demi kepentingan sediri ataupun orang lain dan harta bukanlahsegala-

\footnotetext{
${ }^{32}$ Lihat Schmandt. Op.cit. hlm 85
}

Jurnal TAPIs Vol. 14 No.02 Juli-Desember 2018 


\section{Muh Ide Apurines: PRAKTIK PEMERINTAHAN PADA....}

galanya.

2. Ainda-ndamo karo somanamo lipu (kepentingan negara lebih utama dari kepentingan pribadi) karo adalah diri pribadi, orang seorng atau orang banyak, yang wajib dilindungi keselamatannya oleh negara atau pemerintah namun untuk mempertahankan dan membela kepentingan yang lebih tinggi Lipu (negara), karo atau warga negara rela berkorban demi membela dan mempertahankan lipu sekalipun mengorbankan nyawa mereka. Nilai ini wujud dari pengabdian masyarakat terhadap kepentingannegara.

3. Ainda-indamo lipu somanamo sara, (kepentingan pemerintah lebih utama dari negara) Sara atau negara berazaskan musyawarah adalah milik bersama seluruh rakyat dan pemerintah. Negara wajib dipelihara dan dipertahankan keutuhannya dari bahaya yang menganam dari manapun datangnya. Namun apabila kepentingan yang lebih tinggi dan lebih utama mengendakikeselamatan pemerintah (sara), bagian- bagian negara tertentu dalam keadaan terpaksa bolehdikorbankan

4. Ainda-indamo sara somanamo agama, (agama lebih utama dari pemerintah). Maksudnya apabila eorang atau beberapa orang aparat kesultanan berbuat melanggar peraturan negara atau melanggar hokum yang berlaku, aparat yangbersangkutan wajib disingkarkan dari jabatannya demi keutuhan agama yang menduduki tingkat tertinggi pada falsafah Buton. atau dengan makna lain sara dikatakan bahwa lebih penting dari negara. Namun apabila keadaan yang sangat genting dimana keselamatan sarah benar-benr sudah terancam, dua alternative terpaksa harus diambil; 1) pemerintah menyerah, asalkan agama selamat 2) pemerintah ikut terjun

kemedanperangdengankeyakinanmerakaberjuangdanmatidijalanyan gbenar demi membela kebenaran. ${ }^{33}$

${ }^{33}$ Morsidi, 1990. Undang-undang dasar pemerintahan kerajaan sendiri di Buton. Baubau. Jurnal Hlm 11

Jurnal TAPIs Vol. 14 No.02 Juli-Desember 2018 
Muh Ide Apurines: PRAKTIK PEMERINTAHAN PADA....

\section{Penutup \\ Kesimpulan}

Pertama, proses peralihan sistem pemerintahan pada masa Kesultanan Buton terjadi dua kali, yaitu pada masa peralihan kerajaan ke kesultanan dan pada saat periode sultan ke empat yang merubah dari monarki menjadi monarki kontitusional ditambah praktek demokrasi yang terkandung dalam penyelenggaraan pemerintahannya. Kedua, dalam penyelenggaraan pemerintahaan Kesultanan Buton terjadi praktik demokrasi ala Murtabat Tujuh Sarana Wolio, yang peneliti padukan dengan syarat demokrasi Robert Dahl: 1) Partisipasi efektif dalam Kesultanan Buton, 2) Tanggung jawab politik dalam Kesultanan Buton, 3) Pengawasan agenda dalam ketersediaan lembaga negara di Kesultanan Buton 4) Keterwakilan orang dewasa melalui tahap pemilihan Sultan. Ketiga, keistimewaan konstitusi Kesultanan Buton terlihat dari penerapan niali-nilai falsafah yang terkandung didalamnya dan bisa di terima secara universal oleh semua masyarakat Buton yang berbagai macam suku, seperti halnya falsafah Bhinci-bninciki kuli yang bermaksna empati yang tinggi terhadap sesame manusia.. Jabatan Sultan, pemimpin desa serta masyarakat bisa saling menghormati danmenghargai.

\section{Rekomendasi}

Pertama, perubahan transisi pemerintahan yang terjadi di Kesultanan Butonmengingatkan kembali akan peristiwa transisi pemerintahan Indonesia yang bergulir dari era orde lama, orde baru, dan reformasi. Sehingga menjadikan bahan pembelajaran untuk perbandingan transisi pemerintahan negara Indonesia kecil versi kerajaan dan negara Indonesia pasca kemerdekaan.

Kedua, praktik demokrasi yang terjadi di Kesultanan Butonbelumlah sepenuhnya sempurna seperti halnya demokrasi prosedural yang dipaparkan Robert Dahl, untuk unsur pemangku kepentingan penting dalam struktur pemerintahan tetap di kuasai oleh

Jurnal TAPIs Vol. 14 No.02 Juli-Desember 2018 


\section{Muh Ide Apurines: PRAKTIK PEMERINTAHAN PADA....}

beberapa golongan walaupun dalam proses penyelenggaraan pemerintahannya cenderung terbuka dan lebih demokratis. Ketiga, konstitusi Kesultanan Buton sendiri mulai tersisihkan di masa kini, orang-orang di Pulau Buton sudah mulai melupakan ajaran-ajaran yang tertuang dalam konstitusi tersebut, disinilah peran pemerintah baik Kota Baubau ataupun Provinsi Sulawesi Tenggara untuk melestarikan warisan-warisan leluhur, untuk dilestarikan dan di munculkan kembali sehingga biasa menjadi bahan acuan pembelajaran kedepannya.

\section{Daftar Pustaka}

Abubakar, 1999, Majalah Budaya Buton "Wolio Molagi” Edisi, I, II, III. Kendari: Yayasan WolioMolag,

Agung, Ide Agung Gde. 1985. Dari Negara Indonesia Timur ke Republik Indonesia Serikat. Yogyakarta: Gadjah Mada University Press

Berg, E.J. van den, 1939, Adatgebruiken In Erband Met De Sultansinstallatie In Boeton, TBG. Vol.79

Bungin Burhan, 2001. Metodologi Penelitian Kualitatif. PT Grafindo Persada. Jakarta CorteseoArmado, 1944. The Suma Oriental of Tome Pires. Vol. 1. London: Printed For The Hakluyt Society

Dahl, 2003. Perihal Demokrasi, Yayasan Obor Indonesia, Cetakan Pertama Edisi Terjemahan, Jakarta

Darmawan. 2009. Naskah Buton, Naskah Dunia. Respect. BauBau.

Danandjaja, James., 1994. Folklore Indonesia Ilmu Gosip, Dongen, dan Lain-lain. Jakarta: Grafiti

De Jong, J.J.P., 1998. De Waaier van het Fortuin. Den Haag: der uitgeerij

Hunt Lynn, 1989. The new cultural history. Los Angeles; University of California Press.

Husein A. Chalik dkk, 1985. Sejarah Sosial Daerah Sulawesi Tenggara. Jakarta: Inventarisasi Dan Dokumentasi Depdikbud

Jurnal TAPIs Vol. 14 No.02 Juli-Desember 2018 


\section{Muh Ide Apurines: PRAKTIK PEMERINTAHAN PADA....}

Ikram, 2001, Istiadat Tanah Negeri Buton Edisi Teks dan Komentator, Direktorat Jendral Pendidikan Tinggi, Jakarta.

Kartodirjo, Sartono. 1992. Pendekatan Ilmu Sosial Dalam Metodologi

Sejarah . Jakarta: Gramedia Pustaka Utama

Ligtvoet, A., 1878. Beschrijving en Geshiednis van Boeton. Belanda: Gravehagen. BKI No.26

Muchir, 2003, Sara Pataaguna Memanusiakan Manusia Menjadi Manusia Khalifatullah Di Bumi Kesultanan Butuni. Tarafu. Buton

Moleong. 2013. Metode Peneliatian Kualitatif Edisi Revisi, PT. Remaja Rosdakarya. Bandung.

Purwardi, 2009, Sejarah Sastra Jawa Klasik. Panji Pustaka. Yogyakarta.

Said D., 2006. Menelusuri Jejak Kota Baubau dalam Lintas Sejarah Nusantara. Prisma.

Baubau

Schoorl J.W., 1994. Power, Ideology, And Change In The Early State Of Buton. State And Trade In The Indonesia Archipelago. Belanda: Laiden KITLV Press.

--------., 2003. Masyarakat, Sejarah, dan Budaya Buton.

Djambatan. Jakarta Soekanto, 2001, Hukum adat Indonesia, P.T Raja Grafindo, Jakarta.

Susanto Zuhdi, 2010.Sejerah Buton yang terabaikan Labu Rope Labu Wana, PT Grafindo Persada, Cetakan Pertama, Jakarta.

Pamudji, 1983, Perbandingan Pemerintahan, P.T Bina Aksara, Jakarta Pramudito. 2006. Kitab Negara Kartagama : sejarah tata pemerintahan dan peradilan Keraton Majapahit. gelombang pasang. Yogyakarta

Priyadi Sugeng. 2012. Metode Penelitian Pendidikan Sejarah. Penerbit Ombak. Yogyakarta

Resink, G.J., 1987. Raja dan Kerajaan yang Merdeka di Indonesia 1850-1910: Enam tulisan Terpilih (terjemahan). Jakarta: Penerbit Jambatan

Jurnal TAPIs Vol. 14 No.02 Juli-Desember 2018 


\section{Muh Ide Apurines: PRAKTIK PEMERINTAHAN PADA....}

Rodee,C.C, 1995, Introduction to Political Science edisi terjemahan, P.T Raja grafindo, Jakarta

Tarafu, 1996, Martabat Tujuh Dayanu Ikhsanuddin Jilid 1, Lamra. Buton

Yunus, 1995, Posisi Tasawuf Dalam Sistem Kekuasaan Di Kesultanan Buton Pada Abad Ke-19, Indonesian Netherland Corporation In Islamic Studies, Jakarta.

Zaenu La Ode, 1985, Buton dalam Sejarah Kebudayaan, Suradipa, Surabaya Zahari, 1977, Sejarah Dan Adat Fiy Darul Butuni Jilid, I, II, III, Depdikbud, Jakarta HASIL PENELITIAN DANJURNAL

Aslim, 1995. Kesultanan Buton pada masa pemerintahan

Muhamad Idrus 1824- 1851.Yogyakarta: Skripsi S1

Universitas Gajah Mada

Departeman Agama Republik Indonesia, 2000, Al-Quran dan Terjemahannya, Jakarta: CV. Atlas

Haliadi, 2000. Buton Islam dan Islam Buton: Islamisai, Kolonialisme, dan Sinkretisme.

Yogyakarta: Tesis Pascasarjana UGM

Hasanudin Anwar. Jurnal : Warisan Demokrasi Gorontalo

Jumadi. 2010. Konsep Demokrasi To Manurung. Jurnal Al-Risalah ;

Volume 10 Nomor 2November

Mattulada, H.A., 1993. Kepemimpinan Dan Demokrasi Dalam Tradisi

Masyarakat Nusantara. Ujung Pandang: Majalah Ilmiah

Universitas Hasanuddin Edisi XXIX No.1

Nurhayati, 2003. Sistem Pemerintahan Kesultanan Buton Pada Masa

Kepemimpinan Dayanu Ikhsanuddin, Yogyakarta; Tesis

Program Pascasarjana S2 Universitas Gajah Mada.

Niampe. 2009. Kesultanan Buton dalam Sejarah dan Naskah Nusantara. Kendari. Jurnal Universitas Halu Oleo

Parani,J., 1982. Sumber Tradisional untuk Penulisan Sejarah Buton. Jakarta: Makalah seminar sejarah nasional III

Said D., 1984. Pengaruh Perkembangan Islam Terhadap Masyarakat Buton Abad XV- XX. Ujung pandang; Skripsi S1 FPIPSIKIP

Jurnal TAPIs Vol. 14 No.02 Juli-Desember 2018 
Muh Ide Apurines: PRAKTIK PEMERINTAHAN PADA....

--------., 1993. Sejarah Birokrasi Pemerintahan Pada Masa Kesultanan Buton. Kendari; Laporan hasil penelitian

Saidi, Mohd, dkk, 2001, Studi Sosiologi Cultural Dan Historis Tentang Dasar-Dasar Adat Dan Budaya Masyarakat Buton, Hasil Penelitian Proyek Inentarisasi Adat Dan Budaya Masyarakat Buton, Baubau

Zahari. 1980. Sejarah masuknya islam di Buton dan perkembangannya. Jurnal 